\title{
Brief of Interested Law Professors as Amici Curiae Supporting Petitioner in Brohl v. Direct Marketing Association
}

Richard Pomp

University of Connecticut School of Law

Follow this and additional works at: https://opencommons.uconn.edu/law_papers

Part of the Taxation-State and Local Commons

\section{Recommended Citation}

Pomp, Richard, "Brief of Interested Law Professors as Amici Curiae Supporting Petitioner in Brohl v. Direct Marketing Association" (2016). Faculty Articles and Papers. 536.

https://opencommons.uconn.edu/law_papers/536 
No. $16-458$

\begin{tabular}{|c|c|}
\hline \multicolumn{2}{|c|}{$\begin{array}{c}\text { In the } \\
\text { Supreme Court of the United States }\end{array}$} \\
\hline \multicolumn{2}{|c|}{$\begin{array}{c}\text { BARBARA J. BROHL, in her capacity as Executive } \\
\text { Director of the Colorado Department of Revenue, } \\
\text { Petitioner, }\end{array}$} \\
\hline \multicolumn{2}{|c|}{$\begin{array}{r}\text { THE DIRECT MARKETING ASSOCIATION, } \\
\text { Respondent. }\end{array}$} \\
\hline \multicolumn{2}{|c|}{$\begin{array}{l}\text { On Petition for Writ of Certiorari to the } \\
\text { United States Court of Appeals for the Tenth Circuit }\end{array}$} \\
\hline \multicolumn{2}{|c|}{$\begin{array}{l}\text { Brief of INTERESTED LaW PROFEssors as } \\
\text { AMICI CURIAE Supporting PETITIONER }\end{array}$} \\
\hline $\begin{array}{l}\text { Richard D. Pomp } \\
\text { UNIVERSITY OF } \\
\text { CONNECTICUT } \\
\text { SCHOOL OF LAW } \\
55 \text { Elizabeth Street } \\
\text { Hartford, CT } 06105\end{array}$ & $\begin{array}{l}\text { John Neiman } \\
\text { Counsel of Record } \\
\text { MAYNARD CoOPER \& GALE } \\
\text { 1901 Sixth Avenue North } \\
\text { Regions Harbert Plaza } \\
\text { Suite } 2400 \\
\text { Birmingham, AL } 35203 \\
\text { (205) 254-1228 } \\
\text { jneiman@maynardcooper.c }\end{array}$ \\
\hline
\end{tabular}

November 4, 2016

LEGAL PRINTERS LLC, Washington DC • 202-747-2400 • legalprinters.com 


\section{TABLE OF CONTENTS}

TABLE OF AUTHORITIES ....................................ii

INTEREST OF THE AMICI CURIAE ...................... 1

SUMMARY OF ARGUMENT................................. 2

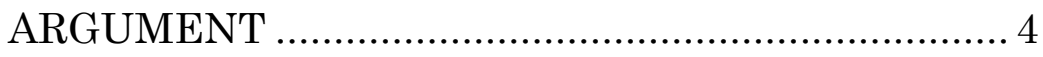

I. The result in Quill appears attributable to an elevated concern for the mail-order industry's reliance interests, faith that the physical presence standard would be workable, and an expectation that Congress would intervene legislatively to address any problems.

A. The opinions in Quill reflect elevated concerns for the mail-order industry's reliance interests compounded by questions regarding the retroactive effect of overruling Bellas Hess.

B. Quill reflects a hope that, despite the artificial nature of the physical presence standard and its failure to embody constitutional principles, the standard would at least be a workable "bright-line" rule........................................... 8

C. Congress's lack of action on this issue does not relieve the Court of its responsibility.

II. To uphold Bellas Hess, the Quill Court took the unprecedented step of bifurcating the standard for state tax jurisdiction, or "nexus." 
CONCLUSION ................................................ 19

APPENDIX: LIST OF AMICI............................ A-1 
iii

\section{TABLE OF AUTHORITIES}

\section{Cases}

Allied-Signal, Inc. v. Dir., Div. of Taxation, 504 U.S. 768 (1992)...........................................5

Camps Newfound/Owatonna, Inc. v. Town of Harrison, 520 U.S. 564 (1997).......................................... 12

Chevron Oil Co. v. Huson, 404 U.S. 97 (1971).........................................5

Cleveland v. U.S., 329 U.S. 14 (1946)

Complete Auto Transit, Inc. v. Brady, 430 U.S. 274 (1977) $15,16,17$

Direct Mktg. Ass'n v. Brohl, 135 S. Ct. 1124 (2015) 3,19

Direct Mktg. Ass'n v. Brohl, 814 F.3d 1129 (10th Cir. 2016) $3,10,13,18$

Freeman v. Hewit, 329 U.S. 249 (1946) $10,16,17$

Goldberg v. Sweet, 488 U.S. 252 (1989)

Harper v. Virginia Dep't of Taxation, 501 U.S. 1247 (1991) 
Harper v. Virginia Dep't of Taxation, 509 U.S. 86 (1993).

Hilton v. South Carolina Public Railways Comm'n, 502 U.S. 197 (1991)

Illinois Brick Co. v. Illinois, 431 U.S. 720 (1977)

James B. Beam Distilling Co. v. Georgia, 501 U.S. 529 (1991)

Landgraf v. USI Film Prod.,

511 U.S. 244 (1994)...................................... 8

Nat'l Geographic Soc'y v. Cal. Bd. of Equalization, 430 U.S. 551 (1977)............................14, 16, 17

Nat'l Bellas Hess, Inc. v. Dep't of Revenue of State of Ill., 386 U.S. 753 (1967) passim

Nw. States Portland Cement Co. v. Minnesota, 358 U.S. 450 (1959)......................................... 16

Patterson v. McLean Credit Union, 491 U.S. 164 (1989). 3,11

Payne v. Tennessee, 501 U.S. 808 (1991) .8

Quill Corp. v. North Dakota, 504 U.S. 298 (1992) passim 
Scripto, Inc. v. Carson, 362 U.S. 207 (1960)

Spector Motor Serv. v. O'Connor, 340 U.S. 602 (1977)

Standard Pressed Steel Co. v. Dep't of Revenue of

Wash.,

419 U.S. 560 (1975)

\section{Other Authorities}

Edward A. Zelinsky, The Political Process

Argument for the Supreme Court to Overrule Quill, 82 BROOK. L. REV. (forthcoming 2017), https://ssrn.com/abstract $=2844470$

H. Beau Baez, Taxing Internet Sales: Trying to Make a Two-Thousand-Year-Old Jurisdiction Test Work in the Dot-Com Economy, 64 TAX LAW. 807 (2011)

Jerome R. Hellerstein \& Walter Hellerstein, State TAXATiON ๆ 19.02 (3d ed. 2012) .................15

John A. Swain, Quexit: The Time Has Come, 81 State Tax Notes 695 (Aug. 29, 2016)...............3

John A. Swain, State Income Tax Jurisdiction: A Jurisprudential and Policy Perspective, 45 WM. \& MARY L. REV. 321 (2003)

Marketplace Fairness Act of 2013,

S. 743, 113th Cong. (2013). 
Marketplace Fairness Act of 2015,

S. 698, 114th Cong. (2015).

Oral Argument, Quill Corp. v. North Dakota,

No. 91-194, 1992 WL 687848 (Jan. 22, 1992) .............................5

Richard D. Pomp, Revisiting Miller Brothers, Bellas Hess, and Quill, 65 AM. U. L. REV. 1115 (2016) ................3, 6, 16, 17

Walter Hellerstein, Taxing Remote Sales In The Digital Age: A Global Perspective, 65 AM. U. L. REV. 1195 (2016)................................. 4

William Joel Kolarik, II, Untangling

Substantial Nexus, 64 TAX LAW. 851 (2011).......................................... 


\section{INTEREST OF THE AMICI CURIAE}

Amici curiae are 14 professors of law who have devoted much of their teaching and research to the area of state taxes and the role of state tax policy in our federal system. The names and affiliations (for identification purposes only) of amici are included in an addendum to this brief. ${ }^{1}$ The amici are concerned with the effect of this Court's dormant Commerce Clause jurisprudence on the development of fair and efficient state tax systems. No decision of this Court has had more effect on state sales and use tax systems than Quill Corporation v. North Dakota. We believe the Tenth Circuit properly decided the case below. But if the Court decides to grant the Direct Marketing Association's petition to review the issue of discrimination which it raises, we respectfully request that the Court also grant the conditional crosspetition filed by Executive Director Barbara J. Brohl of the Colorado Department of Revenue asking the Court to reconsider Quill. This brief sets forth the reasons for our support of that cross-petition.

\footnotetext{
${ }^{1}$ No counsel for any party authored this brief in whole or in part nor made any monetary contribution. Only amici curiae or their counsel made any monetary contribution to the preparation or submission of this brief. Counsel of record for the parties received timely notice of the intent to file this brief and have granted consent.
} 


\section{SUMMARY OF ARGUMENT}

In Nat'l Bellas Hess, Inc. v. Dep't of Revenue of State of Ill., 386 U.S. 753 (1967), this Court held, over a rigorous dissent, that Illinois could not constitutionally require a mail-order seller with no office, agents, solicitors or property in the state to collect use taxes on its sales. In Quill Corp. v. North Dakota, 504 U.S. 298 (1992), the Court reconsidered this holding. North Dakota did not allege that Quill was factually distinguishable from Bellas Hess. See Quill, 504 U.S at 303. Instead, the state took on the harder task of arguing that changes in the Court's Due Process and Commerce Clause jurisprudence had made Bellas Hess obsolete. Id. at 303-04. The Court agreed with North Dakota that both its Due Process and Commerce Clause jurisprudence had "evolved substantially." Quill, 504 U.S at 307, 309.

But the Court nevertheless overruled Bellas Hess only on Due Process Clause grounds. The Court not only sustained Bellas Hess under the Commerce Clause, but also breathed new life into its holdingcreating what is now referred to as the "physical presence" nexus standard for use tax collection. This result can only be explained by the Court's desire to remove due process obstacles to Congressional intervention while protecting the interests of the mailorder industry under the Commerce Clause. These concerns led to an unprecedented bifurcation of the standard for state tax jurisdiction or "nexus" between the Due Process and Commerce Clauses, a

distinction that has not been extended to other areas but has instead become a "precedential island." See 
Direct Mktg. Ass'n v. Brohl, 814 F.3d 1129, 1151 (10th Cir. 2016)(“DMA II")(Gorsuch, J. concurring).

For more than two decades, states like Colorado have endeavored without success to adapt the necessities of sales and use tax enforcement to the physical presence standard, especially in a digital world. Now some states are considering another direct challenge, this time to Quill. ${ }^{2}$ Indeed, Justice Kennedy has stated that the legal system should find the appropriate case to consider a challenge to Quill. See Direct Mktg. Ass'n v. Brohl, 135 S. Ct. 1124, 1135 (2015)(Kennedy, J., concurring)(“DMA I'). This Court's precedents are not "sacrosanct;" rather, they can be overruled where "the necessity and propriety of doing so has been established," Patterson $v$. McLean Credit Union, 491 U.S. 164, 172 (1989), especially when they have become anachronistic, Quill 504 U.S. at 331 (White, J. concurring in part and dissenting in part).

We leave it to others to expound the ways in which the physical presence standard has proven to be unworkable. Dozens of scholarly articles have addressed the topic. ${ }^{3}$ For our part, we contend the

2 John A. Swain, Quexit: The Time Has Come, 81 State TAX NoTES 695 (Aug. 29, 2016).

${ }^{3}$ See, e.g., John A. Swain, Quexit: The Time Has Come, supra; H. Beau Baez, Taxing Internet Sales: Trying to Make a TwoThousand-Year-Old Jurisdiction Test Work in the Dot-Com Economy, 64 TAX LAW. 807 (2011) William Joel Kolarik, II, Untangling Substantial Nexus, 64 TAX LAW. 851 (2011); Richard D. Pomp, Revisiting Miller Brothers, Bellas Hess, and Quill, 65 AM. U. L. REV. 1115 (2016); Walter Hellerstein, Taxing Remote Sales In The Digital Age: A Global Perspective, 65 AM. U. L. REV. 1195 (2016). 
standard has no support under established constitutional principles. If the Court chooses to grant the DMA's petition in this case, it should also grant Colorado's conditional cross-petition to reconsider Quill.

\section{ARGUMENT}

I. The result in Quill appears attributable to an elevated concern for the mail-order industry's reliance interests, faith that the physical presence standard would be workable, and an expectation that Congress would intervene legislatively to address any problems.

Because the Quill Court was not writing on a clean slate, it sustained the Commerce Clause holding in Bellas Hess to accommodate certain concerns, creating a physical presence standard as the "nexus" requirement for use tax collection. In doing so, it elevated the mail-order industry's reliance interests over other competing interests, disregarding the sound constitutional principles which the opinions in Quill recognize. The Court's rationale also reflected faith that the physical presence standard would, at least, be workable, and if not, the expectation that Congress would change it.

A. The opinions in Quill reflect elevated concerns for the mail-order industry's reliance interests compounded by questions regarding the retroactive effect of overruling Bellas Hess.

Whether a decision to overrule Bellas Hess should be given retroactive effect was the " 800 -pound goril- 
la" in Quill. Quill's petition for writ of certiorari had set forth the issue as a separate question from whether Bellas Hess remained good law. ("Whether the North Dakota Supreme Court may give retroactive effect to its decision, which is contrary to established constitutional precedent, to make Quill liable for uncollected use taxes back to July 1, 1987?") The Court did not grant certiorari on that issue, Quill, 504 U.S at 332 (White, J. concurring in part and dissenting in part). Nonetheless, some Justices expressed concerns about retroactivity during oral argument. See Oral Argument, Quill Corp. v. North Dakota, No. 91-194, 1992 WL 687848 (Jan. 22, 1992).

The Court's apparent ambivalence is perhaps understandable. Quill came to the Court amid its reexamination of whether its rulings might be given prospective rather than retroactive effect. See James $B$. Beam Distilling Co. v. Georgia, 501 U.S. 529 (1991); Harper v. Virginia Dep't of Taxation, 501 U.S. 1247 (1991)(Harper I); and Harper v. Virginia Dep't of Taxation, 509 U.S. 86 (1993)(Harper II)(where the Court reconsidered its precedent on prospective application under Chevron Oil Co. v. Huson, 404 U.S. 97 (1971)). Just a few weeks after Quill, the Court, citing Beam, noted the "difficult questions" raised when a precedent is overruled retroactively. AlliedSignal, Inc. v. Dir., Div. of Taxation, 504 U.S. 768, 785-86 (1992). Under Harper II, the Court held that its decisions are presumed to have retroactive effect when applied to the parties before it. 509 U.S. at 97 (1993).

Because the Court did not take up the question of retroactivity in Quill, North Dakota did not have the 
opportunity to discuss the contours of that doctrine nor to challenge the legitimacy of the industry's purported reliance interests including whether leaving Bellas Hess in place was necessary to accommodate those interests. The majority in Quill could simply assert that "it is not unlikely that the mail-order industry's dramatic growth over the last quarter century is due in part to the bright-line exemption from state taxation created in Bellas Hess," Quill, 504 U.S at 316 , concluding that the "Bellas Hess rule ... has become part of the basic framework of a sizable industry," Id. at 317 (emphasis added). Justice White's partial dissent, in contrast, notes that neither Quill nor its amici cited any investment decisions that would have changed had the mail-order industry believed Bellas Hess was no longer the rule. Quill at 331-32.

Contrary to the Court's assertion in Quill, the growth of the mail-order industry was likely facilitated by many things, including the advent of national credit cards, such as MasterCard and Visa, the innovation of the toll-free 800-telephone call, and the expansion of the United Parcel Service (UPS) and Federal Express. How much of that growth was due to the advantage of not having to collect tax is, at best, a tricky empirical question. Richard D. Pomp, Revisiting Miller Brothers, Bellas Hess, and Quill, 65 AM. U. L. REV. 1115, 1141 (2016).

The majority in Quill expressed much less concern for competing interests. Shielding certain sellers from tax collection obligations would certainly pose economic drawbacks for competitors required to collect taxes. Nor did the majority consider the sub- 
stantial tax enforcement problems that would be created for the states. But most critically, the majority did not address whether it was reasonable for the mail-order industry to have relied so extensively on Bellas Hess as to make its holding part of the "foundation" for that industry's growth. Arguably, such reliance would have required the rule in Bellas Hess to be frozen in time.

The Courts in both Bellas Hess and Quill gave no indication that they expected that a rule designed to protect the reliance interests of a part of a single industry (mail-order sellers without physical presence) would come to constitute the rule for an emerging industry built on the Internet. Should this Court decide to overturn Quill, it can do so while respecting the reasonable reliance interests of sellers without physical presence, which extend to avoiding retroactive liabilities for uncollected taxes. Any retroactive liabilities must have two separate causes-the first being a decision to overrule Quill, which would be presumed to have retroactive effect if it were applied to the parties in this case-but need not be so applied. But the second cause of any retroactive liabilities would be the statutes requiring tax collection that might spring into effect in many states after the limitation in Quill is removed. Allowing this kind of retroactive liability, however, contravenes a longestablished principle that legislative enactments, unlike this Court's rulings, are presumed to have prospective effect. This presumption is founded in the Due Process Clause, which provides for fair notice and repose, interests that may be compromised by retroactive legislation. See Landgraf $v$. USI Film Prod., 511 U.S. 244, 266 (1994). If the Court were to 
overrule Quill, these same "interests in fair notice" that underpin this presumption would justify making that ruling prospective. Further, if the Court found that Quill has become unworkable, holding that it continues to apply until the point at which it is adjudicated unworkable, rather than applying it retroactively, would be consistent with principles of stare decisis. Payne v. Tennessee, 501 U.S. 808, 827 (1991)("[W]hen governing decisions are unworkable or are badly reasoned, "this Court has never felt constrained to follow precedent.").

\section{B. Quill reflects a hope that, despite the artificial nature of the physical pres- ence standard and its failure to em- body constitutional principles, the standard would at least be a workable "bright-line" rule.}

The Quill Court clearly put its faith in the practical workability of the "bright-line" physical-presence standard. Our purpose here is not to demonstrate the many ways in which, with the advent of electronic commerce, this standard has failed to justify that faith. Instead, we demonstrate that the physicalpresence standard cannot be derived from fundamental constitutional principles, and if it has become unworkable, it need not be sustained as though it reflected or embodied those principles.

The majority in Quill defended the physical presence standard as a bright-line test despite admitting it "appears artificial at its edges." Quill, 504 U.S at 315 . With hindsight, it is obvious that the artificiality of the physical-presence standard extends well 
beyond "the edges." Under that standard, a small business with a few employees in multiple states will have multiple tax collection obligations, whereas a much larger Internet seller with no presence in the same states will not.

It is telling that the three opinions in Quill use the term "physical presence" a total of 27 times and the term "bright-line" 15 times. And yet no precedent cited by the Quill Court, including Bellas Hess, uses either term. In 1992, the distinction that had been made in Bellas Hess between mail-order sellers with instate retail offices versus those without, was simple enough to draw. But there is no evidence the Court considered the viability of a physical presence standard going forward. See Quill, 504 U.S at 321 (Scalia, J. concurring in part and concurring in the judgment)(looking only at the period from 1967 to 1992 for proof that the standard would be workable).

Even less attention was paid to whether the standard was required by constitutional principles. This question was raised mainly by the dissents in Bellas Hess and Quill. To the dissent in Bellas Hess, the line between mail-order sellers with and without retail outlets, solicitors, or property was simply not grounded in the fundamental constitutional principle cited by the majority - that a state could impose a burden on an out-of-state seller in exchange for the benefits it provided if the burden did not exceed that imposed on local commerce. Bellas Hess, 386 U.S. at 765-66. (Fortas, J., dissenting) And it was undeniable that the burden to be imposed on the mail-order sellers was no greater than that imposed on other sellers. Id. at 766 . Moreover, that burden was argu- 
ably comparable to other tax and regulatory burdens that states could continue to impose on mail-order sellers. See DMA II at 1149 (Gorsuch, J. concurring)(citing Quill, 504 U.S at 311-12).

Justice White, in his partial dissent in Quill, contended that the artificial distinction made in Bellas Hess between mail-order sellers was no different than similar formalistic rulings in Freeman v. Hewit, 329 U.S. 249 (1946) and Spector Motor Serv. v. O'Connor, 340 U.S. 602 (1977), which the Court had abandoned as unworkable and unprincipled. Quill, 504 U.S at 322 (concurring in part and dissenting in part). Justice White concluded: "The majority clings to the physical-presence rule not because of any logical relation to fairness or any economic rationale related to principles underlying the Commerce Clause, but simply out of the supposed convenience of having a bright-line rule." Id. at 329. It was a "sure bet", said Justice White that "the vagaries of "physical presence' will be tested to their fullest in our courts." Id. at 331. Although the concurring opinion dismissed these concerns, see Quill, 504 U.S at 320-21 (Scalia, J., concurring in part and concurring in the judgment), they have been vindicated in the Internet age.

\section{Congress's lack of action on this issue does not relieve the Court of its re- sponsibility.}

By bifurcating the constitutional basis for state tax jurisdiction (discussed further in Section II) and removing the due process obstacle to Congressional intervention, the Court left Congress "free to decide 
whether, when, and to what extent the states may burden interstate mail-order concerns with a duty to collect use taxes." Quill, 504 U.S. at 318. The majority admitted this also made its decision easier saying " $[\mathrm{t}]$ his fact alone" was enough to keep it from overturning Bellas Hess "at least for now." Id. at 318-19.

The concurring opinion in Quill expressed a similar expectation that Congress could change the rule of Bellas Hess "by simply saying so." Id. at 320 (Scalia, J., concurring in part and concurring in the judgment). The concurrence also justifies this decision, saying: "We have long recognized that the doctrine of stare decisis has 'special force' where 'Congress remains free to alter what we have done." Id. As authority for this proposition, however, the concurrence cites decisions upholding the Court's earlier construction of federal statutes, rather than cases involving the Court's dormant Commerce Clause rulings. See Quill, 504 U.S. at 320 (citing Patterson v. McLean Credit Union, 491 U.S. 164, 172-173 (1989)(42 U.S.C.A. § 1981), Hilton v. South Carolina Public Railways Comm'n, 502 U.S. 197, 202 (1991)(the Federal Employers' Liability Act); and Illinois Brick Co. v. Illinois, 431 U.S. 720, 736 (1977)(the Clayton and Sherman Acts)).

The idea that the Court may "shift to Congress the responsibility for perpetuating the Court's error," see Cleveland v. U.S., 329 U.S. 14, 22 (1946) (Rutledge, J. concurring), is problematic. As Justice Rutledge underscored in Cleveland, there are "vast differences between legislating by doing nothing and legislating by positive enactment." Id. The reasons 
Congress may fail to take corrective action include the sheer pressure of other more important business, political considerations, and "a strong and proper tendency to trust to the courts to correct their own errors." Id. at 22-23. Further, according to Justice Rutledge:

The danger of imputing to Congress, as a result of its failure to take positive or affirmative action through normal legislative processes, ideas entertained by the Court concerning Congress' will, is illustrated most dramatically perhaps by the vacillating and contradictory courses pursued in the long line of decisions imputing to the silence of Congress' varied effects in commerce clause cases.

Id. (emphasis added, internal citations omitted). ${ }^{4}$ See also Camps Newfound/Owatonna, Inc. v. Town of Harrison, 520 U.S. 564, 617 (1997)(Thomas, J. dissenting)("treating unenacted congressional intent as if it were law would be constitutionally dubious").

${ }^{4}$ After Quill, Congress expressed little interest in legislation addressing this issue until the Senate passed the Marketplace Fairness Act in 2013. That proposal languished in the House and was never enacted. Marketplace Fairness Act of 2013, S. 743, 113th Cong. (2013) GovTraCK.US, https://www.govtrack.us/congress/ bills/113/s743 (last visited May 17, 2016). The bill has been reintroduced in the Senate and referred to Committee. Marketplace Fairness Act of 2015, S. 698, 114th Cong. (2015), https://www.congress.gov/bill/114th-congress/senatebill/698/related-bills (last visited May 17, 2016) (providing the status of legislation pending in Congress). Similar legislation was introduced in the House but never voted on. 
These points are as true today as when Justice Rutledge expressed them.

Today, Congress would face additional hurdles in enacting legislation overruling Quill: divergent and competing business interests, conflicting state interests, and the mistaken view by many consumers that Internet sales are simply "tax free" and that any tax collected would be tantamount to a "new" tax. Congress may be unable to act even if a majority favors eliminating the physical presence rule. See also Edward A. Zelinsky, The Political Process Argument for the Supreme Court to Overrule Quill, 82 BrooK. L. REV. (forthcoming 2017), available at https://ssrn.com/abstract=2844470 (last visited Oct. $28,2016)$.

\section{To uphold Bellas Hess, the Quill Court took the unprecedented step of bifurcating the standard for state tax jurisdiction, or "nex- us."}

This Section examines Quill's unprecedented bifurcation of the standard for state tax jurisdiction, or "nexus," between the Due Process and Commerce Clauses. This was a controversial idea, as acknowledged by Judge Gorsuch below, who described Quill in these terms: "Everyone before us acknowledges that Quill is among the most contentious of all dormant commerce clause cases. Everyone before us acknowledges that it's been the target of criticism

over many years from many quarters, including from many members of the Supreme Court." DMA II, 814 F.3d at 1148 (concurring opinion). 
No dispute exists that the Commerce Clause imposes limitations on state taxing powers in addition to what the Due Process Clause imposes. See Quill, 504 at 305. Prior to Quill, however, the Court had little reason to precisely distinguish whether its rulings on state nexus were grounded in one clause or the other. See, e.g., Standard Pressed Steel Co. v. Dep't of Revenue of Wash., 419 U.S. 560, 562, 564 (1975)(referencing both the Due Process Clause and the Commerce Clause); Nat'l Bellas Hess, Inc. $v$. Dep't of Revenue, 386 U.S. 753, 756 (1967)(the "two claims are closely related"). In any case, while the nexus standard might be based in both the Due Process and Commerce Clauses, the Court never held that the standard would not be the same under both clauses. See, e.g. Nat'l Geographic Soc'y v. Cal. Bd. of Equalization, 430 U.S. 551, 554 (1977)(stating that: "The question presented by this case is whether the Society's activities at the offices in California provided sufficient nexus . . . as required by the Due Process Clause of the Fourteenth Amendment and the Commerce Clause"); see also Quill, 504 U.S. at 304 (describing Bellas Hess as relying on both the Due Process Clause and the Commerce Clause).

Bifurcating and distinguishing the nexus standard between the Due Process Clause, which Quill satisfied, and the Commerce Clause, which Quill did not, served two purposes. By holding that Quill had nexus under the Due Process Clause, the Court removed the constitutional obstacle to Congress's intervention by negating any due process right of "remote" vendors to be free of state use tax collection duties. At the same time, however, because Quill had no Commerce Clause nexus, it could not be made to 
collect the North Dakota use tax. This protected the mail order industry's perceived reliance interests.

This approach of creating a different nexus standard under the Due Process Clause from that under the Commerce Clause was unprecedented, and it came at a high jurisprudential cost. The Court sought support for its approach in one case, Complete Auto Transit, Inc. v. Brady, 430 U.S. 274, 289 (1977), and that case's single use of the term "substantial nexus." Complete Auto was a Commerce Clause case and, according to the Quill Court, the use of "substantial nexus," as opposed to just "nexus," supported a different meaning under the Commerce Clause than under the Due Process Clause. As leading scholars observed, "the Court's discovery that '[d]espite the similarity in phrasing, the nexus requirements of the Due Process and Commerce Clauses are not identical' is more accurately viewed as a doctrinal epiphany than as a logical inference to be drawn from the careful reading of its precedents." See Jerome R. Hellerstein \& WALter HellerStein, State TaXation 19.02 (3d ed. 2012). Ironically, in Complete Auto, the question of the nexus standard was not even before the Court because the taxpayer acknowledged that it was not challenging nexus. Complete Auto at 276-78. Anything the Court might have said about nexus was merely dicta.

Also, standing in contrast to Complete Auto's one-time use of "substantial nexus" was the Court's reference to "sufficient nexus" or "sufficiently connected" elsewhere in the opinion. See, e.g., id. at 278, 285. Additionally, Complete Auto cites cases referring to nexus in more traditional due process con- 
texts as a "necessary connection," id. at 280-81 (citing Freeman v. Hewit, 329 U.S. 249, 271 (1946) (Rutledge, J., concurring), or as "sufficient nexus," $i d$. at 285 (citing Nw. States Portland Cement Co. v. Minnesota, 358 U.S. 450 (1959)). Complete Auto's one-time use of "substantial nexus" in a case not involving nexus can hardly be read as announcing a new Commerce Clause meaning for the concept. Indeed, the term "substantial nexus" never appears in a tax context prior to Complete Auto and had no history attached to it. And in Nat'l Geographic Soc'y v. Cal. Bd. of Equalization, decided less than a month after Complete Auto, the Court stated:

The question presented by this case is whether the Society's activities at the offices in California provided sufficient nexus between the out-of-state seller appellant and the [s]tate-as required by the Due Process Clause of the Fourteenth Amendment and the Commerce Clause-to support the imposition upon the Society of a use-tax-collection liability.

430 U.S. 551, 554 (1977)(emphasis added). In short, it is difficult to believe that the one-time use of the term "substantial nexus" in Complete Auto can bear the weight Quill put on that term. See also Richard D. Pomp, Revisiting Miller Brothers, Bellas Hess, and Quill, supra, at 1145-47.

Moreover, formulating a new nexus standard based on traditional Commerce Clause principles alone is fraught with difficulty. As noted in Section I, the Quill Court never explained why a company's 
physical presence in a state is related to the Commerce Clause value of limiting state burdens on interstate commerce. Quill, 504 U.S. at 314-15. According to the majority in Quill, the Commerce Clause and the substantial nexus requirement reflect structural concerns about the effects of state regulation on the national economy and interstate commerce. $I d$. at 311-13. Yet the majority fails to explain in what way the burden on interstate commerce of collecting the use tax is reduced when a mail-order seller has property in the state, see Nat'l Geographic Soc'y v. Cal. Bd. of Equalization, 430 U.S. 551, 562 (1977) (a company's office in the market state soliciting advertisements for the company's magazine "provide[d] a sufficient nexus" between the company and the market state), or when a seller has engaged the services of ten part-time, independent contractors within the state, see Scripto, Inc. v. Carson, 362 U.S. 207, 211, 213 (1960). See Richard D. Pomp, Revisiting Miller Brothers, Bellas Hess, and Quill, supra, at 1144. And while Justice Rutledge had suggested in his Freeman concurrence that the requirement of some local incident might act as a safeguard to multiple or duplicative taxation, 329 U.S. at 260261, that issue has now been addressed under Complete Auto's "fair apportionment" prong, see Goldberg v. Sweet, 488 U.S. 252, 259-61 (1989).

Neither in Complete Auto, nor in any other case cited by Quill, has the Court found sufficient contacts for due process purposes but an insufficient nexus under the Commerce Clause. Quill, 504 U.S. at 325 (White, J. concurring in part and dissenting in part). And not since Quill has the Court seen a need to have a different nexus standard under the 
Due Process and Commerce Clauses. Moreover, the lower courts have generally interpreted Quill narrowly, even in the state tax context. See John A. Swain, State Income Tax Jurisdiction: A Jurisprudential and Policy Perspective, 45 WM. \& MARY L. REV. 321 (2003)(chronicling how the physical presence standard was not adopted in the corporate income tax context and the policy and other reasons for distinguishing Quill).

As Judge Gorsuch noted in his concurrence in $D M A I I$, "[i]t may be rare for Supreme Court precedents to suffer as highly a 'distinguished' fate . . ." $D M A$ II, 814 F.3d at 1150 . But the explanation for that fate is simple: Quill adds nothing substantive to the constitutional framework that undergirds state tax nexus. As a decision resulting from expediency, Quill cannot be sustained on principle. 


\section{CONCLUSION}

In 2015, Justice Kennedy described Quill as "questionable even when decided" and said it "should be left in place only if a powerful showing can be made that its rationale is still correct." DMA I, 135 S. Ct. 1124, 1135 (concurring opinion). As we have argued here, the rationale for Quill was one driven entirely by practical concerns, rather than constitutional principles. Justice Kennedy also expressed the view that " $[t]$ he legal system should find an appropriate case for this Court to reexamine Quill and Bellas Hess." Id. If the Court determines it is necessary to accept the DMA's petition for certiorari, it should not wait to reexamine Quill in some later case, but should accept Colorado's cross-petition.

Respectfully submitted,

$\begin{array}{ll}\text { Richard D. Pomp } & \begin{array}{c}\text { John C. Neiman, Jr. } \\ \text { Counsel of Record } \\ \text { UNIVERSITY OF }\end{array} \\ \text { CONNECTICUT } & \text { 1901 Sixth Avenue North } \\ \text { SCHOOL OF LAW } & \text { 2400 Regions/Harbert Plaza } \\ \text { 55 Elizabeth Street } & \begin{array}{l}\text { Birmingham, AL 35203 } \\ \text { (205) 254-1228 } \\ \text { Hartford, CT 06105 }\end{array} \\ & \text { jneiman@maynardcooper.com }\end{array}$


A-1

\section{APPENDIX: LIST OF AMICI}

The interested law professors (in alphabetical order) are:

Joseph Bankman

Ralph M. Parsons Professor of Law and Business

Stanford Law School

Crown Quadrangle

559 Nathan Abbott Way

Stanford, CA 94305-8610

Jordan M Barry

Herzog Endowed Scholar and Professor of Law

University of San Diego School of Law

5998 Alcalá Park

San Diego, CA 92110-2492

Robert J. Desiderio

Emeritus Professor of Law

University of New Mexico School of Law

1117 Stanford NE MSC11 6070,

1 University of New Mexico

Albuquerque, NM 87131-0001

David Gamage

Assistant Professor of Law

University of California, Berkeley, School of Law

889 Simon Hall

Berkeley, CA 94720 MC:7200 
Andy Haile

Associate Dean for Academic Affairs and Associate

Professor of Law

Elon University School of Law

201 North Greene Street

Greensboro, NC 27401

Richard Handel

Adjunct Professor

University of South Carolina School of Law

701 Main Street

Columbia, South Carolina 29208

Hayes Holderness

Visiting Assistant Professor and Ribstein Fellow

University of Illinois College of Law

504 East Pennsylvania Avenue

Champaign, Illinois 61820

Richard D. Pomp

Alva P. Loiselle Professor of Law

University of Connecticut School of Law

55 Elizabeth Street

Hartford, CT 06105-2290 USA

Darien Schanske

Professor of Law

University of California, Davis, School of Law

King Hall

400 Mrak Hall Drive

Davis, CA 95616-5201 
Erin A. Scharff

Associate Professor of Law

Arizona State University Sandra Day O'Connor

College of Law

MC 9520

111 E. Taylor Street

Phoenix, AZ 85004-4467

Kirk Stark

Barrall Family Professor of Tax Law and Policy

UCLA School of Law

385 Charles E. Young Drive East

1242 Law Building

Los Angeles, California 90095

John Swain

Chester H. Smith Professor of Law

University of Arizona James E. Rogers

College of Law

1201 E. Speedway

Tucson, Arizona 85721

Dennis J. Ventry, Jr.

Professor of Law

University of California, Davis, School of Law

King Hall

400 Mrak Hall Drive

Davis, CA 95616-5201

Edward Zelinsky

Morris and Annie Trachman Professor of Law

Cardozo School of Law

55 Fifth Avenue, Room 941

New York, NY 10003 